\title{
ANALISIS PERFORMA LOAD TIME SISTER MENGGUNAKAN LAYANAN KAMPUSGOPUBLIC
}

\section{Firman Pratama}

Universitas Pamulang Tangerang Selatan, Indonesia

Email: dosen02407@unpam.ac.id

\begin{abstract}
Abstrak
SISTER merupakan sebuah aplikasi berbasis web yang berjalan menggunakan Virtual Box. SISTER diinisiasi pertama kali oleh Kemristekdikti pada tahun 2017 dan wajib diterapkan oleh seluruh Perguruan Tinggi di Indonesia. SISTER dipergunakan untuk layanan administrasi Dosen Perguruan Tinggi. Kondisi dilapangan belum seluruh Perguruan Tinggi menjalankan aplikasi SISTER dengan baik dengan berbagai permasalahan teknis yang ada yaitu SISTER hanya dapat diakses melalui jaringan private Perguruan Tinggi, Sehingga Dosen yang memiliki mobilitas tinggi sulit untuk mengakses SISTER dari jaringan publik atau internet. Agar SISTER dapat diakses dari internet dibutuhkan IP Public yang biasanya disediakan oleh Internet Service Provider (ISP) atau cloud service provider yang membutuhkan biaya yang relatif mahal. KampusGoPublic menyediakan alternatif untuk Perguruan Tinggi yang ingin membuat SISTER yang telah berjalan pada jaringan private Perguruan Tinggi masing-masing dapat diakses melalui jaringan internet dengan terhubung melalui VPN dengan protocol SSTP ke VPN Server KampusGoPublic. Untuk menganalisa performa protocol SSTP pada layanan KampusGoPublic yang digunakan oleh Akademi Pariwisata Nusantara Jaya diperlukan pengujian. Metode yang digunakan mengadopsi metode eksperimen. Pengujian menggunakan teknik page load time untuk mencari waktu rata-rata yang diperlukan untuk host dalam menampilkan halaman web server SISTER yang berada pada jaringan private. Sehingga packet pada server private akan melewati SSTP server untuk dapat diakses dari jaringan publik. Berdasarkan hasil pengujian Page Load Time rata-rata, layanan KampusGoPublic yang menggunakan protocol SSTP berjalan dengan baik dengan waktu load page tercepat 1,75 detik pada mode Cache Enable dan 3,78 pada mode Cache Disable sehingga metode SSTP dianggap ideal sebagai bridging data antara server yang ada pada jaringan private dan VPN Server untuk dapat dihubungkan ke jaringan publik.
\end{abstract}

Kata Kunci: SISTER; VPN; SSTP; Load Time; Tunneling

\section{Abstract}

SISTER is a web-based application that runs using Virtual Box. SISTER was first initiated by the Ministry of Research, Technology and Higher Education in 2017 and must be applied by all universities in Indonesia. SISTER is used for university lecturer administration services. In the field conditions, it was found that not all universities have run the SISTER application properly with various technical problems, namely SISTER can only be accessed through the university's private network, so that Lecturers who have high mobility are difficult to access SISTER

$\begin{array}{ll}\text { How to cite: } & \text { Pratama, F., (2022) Analisis Performa Load Time Sister Menggunakan Layanan KampusGoPublic, Syntax } \\ & \text { Idea, 4(1), https://doi.org/10.36418/syntax-idea.v4i1.1736 } \\ \text { E-ISSN: } & \text { 2684-883X } \\ \text { Published by: } & \text { Ridwan Institute }\end{array}$


from public networks or the internet. In order for SISTER to be accessed from the internet, a Public IP is needed which is usually provided by an Internet Service Provider (ISP) or cloud service provider which requires relatively expensive costs. Campus GoPublic provides an alternative for Universities who want to make SISTER that is already running on a private university network, each of which can be accessed via the Internet by connecting via a VPN with the SSTP protocol to the GoPublic Campus VPN Server. To analyze the performance of the SSTP protocol on the KampusGoPublic service used by the Nusantara Jaya Tourism Academy, testing is needed. The method used is an experimental method. The test uses the page load time technique to find the average time required for the host to display the SISTER web server page on a private network. So that the packet on the private server will pass through the SSTP server to be accessed from the public network. Based on the results of the average Page Load Time test, the KampusGoPublic service that uses the SSTP protocol runs well with the fastest page load time of 1.75 seconds in Cache Enable mode and 3.78 in Cache Disable mode so that the SSTP method is considered ideal for bridging data between servers. on a private network and a VPN Server to be connected to a public network.

Keywords: SISTER; VPN; SSTP; Load Time; Tunneling

\section{Received: 2021-12-22; Accepted: 2022-01-05; Published: 2022-01-20}

\section{Pendahuluan}

SISTER merupakan program yang diinisialisasi oleh Kemristekdikti pada tahun 2017. Selanjutnya pada tahun 2021 sesuai dengan nomenklatur Presiden, Pendidikan Tinggi (Dikti) dilebur ke dalam Kemdikbud menjadi Kemdikbudristek sehingga menghasilkan perubahan pengelolaan SISTER menjadi di bawah Kemdikbudristek. SISTER merupakan sebuah sistem yang wajib di implementasi pada setiap Perguruan Tinggi yang ada di Indonesia sebagai layanan administrasi para dosen. Berdasarkan kondisi dilapangan masih banyak Perguruan Tinggi yang masih kesulitan implementasi SISTER organisasinya, mulai dari keterbatasan infrastrutur dan anggaran untuk mengimplementasikan SISTER sesuai dengan standar Kemdikbudristek. Agar SISTER dapat berjalan dengan baik dibutuhkan kemudahan dalam dosen dan operator mengakses SISTER bukan hanya dari jaringan komputer private Perguruan Tinggi saja tetapi dari mana saja selama terkoneksi dengan internet.

KampusGoPublic sebagai layanan non-profit penyedia IP Public, VPN server dengan protocol SSTP serta Port Forwarding untuk membantu kampus yang tidak memiliki IP public untuk server SISTER. Sehingga dapat memberikan alternatif agar server SISTER kampus dapat diakses melalui internet untuk memudahkan dosen dan operator dalam menggunakan SISTER.

Pada pengujian perbandingan SSTP \& OpenVPN yang dilakukan (Aleshin, I.; Vasiliev, A.; Kholodkov, K.; Perederin, 2015) menghasilkan kesimpulan pada jaringan yan tidak stabil dengan throughput yang rendah, kapasitas SSTP lebih tinggi dibandingkan OpenVPN. (Farly et al., 2017) melakukan implementasi dan pengujian protocol SSTP dan L2TP yang menghasilkan kesimpulan total packet loss pada SSTP 
terhadap 20 kali percoban pengiriman lebih kecil dibandingkan protocol L2TP. Pengujian QOS (Azhar, 2017) mencoba membandingkan antara kualitas jaringan dengan VPN dan non-VPN yang menghasilkan kesimpulan bahwa kualitas delay pengiriman paket yang menggunakan protocol SSTP jauh lebih kecil dibandingan jaringan tanpa protocol VPN. Pengujian yang dilakukan (Carol et al., 2017) menyatakan bahwa protocol SSTP lebih unggul dibandingkan dengan protocol PPTP dalam hal pengujian file transfer serta file download. (Hariyadi, 2017) menggunakan protocol SSTP sebagai bridging antar router yang berbeda sehingga router dapat berkomunikasi antara satu dengan router lainnya pada jaringan SSTP. Pada publikasi lainnya, (Hariyadi \& Azhar, 2017) menerapkan SSTP untuk mengamankan proses transfer file antara server cloud storage dan host yang ada pada jaringan STMIK Bumigora, sehingga packet yang melewati jaringan tunnel dapat terinkripsi. Pada penelitian (Zamalia et al., 2018) membandingkan antara QoS PPTP, L2TP, SSTP dan IPSec yang menyatakan bahwa IPSec merupakan protocol yang paling aman antara 3 Protocol lainnya sedangkan dari sisi manajemen packet loss protocol SSTP lebih baik pada pengujian kasus streaming. (Sugiyatno \& Atika, 2018) melakukan penerapan SSTP menggunakan Raspberry Pi dengan software Softether VPN Server, pada metode pengujian packet sniffing SSTP lebih aman untuk melakukan proses encrypt pada packet sehingga isi packet tidak dapat dibaca ketika melewati suatu jaringan. Berdasarkan implementasi (Ruslianto, Ikhwan;Ristian, 2019) SSTP digunakan sebagai solusi akses yang aman ke dalam jaringan internal kampus untuk keperluan penggunaan sistem informasi fakultas.Pada pengujian (Rasuanda \& Haeruddin, 2020) menghasilkan kesimpulan bahwa VPN dengan protocol SSTP mampu menembus firewall dikarenakan menggunakan transport protocol TCP dengan port 443. (Santoso et al., 2021) menerapkan site to site VPN dengan menggunakan protocol L2TP dan IPSec untuk menghubungkan dengan jaringan antar devisi yang berbeda.

Berdasarkan referensi yang didapatkan, belum ada pengujian yang dilakukan untuk menguji performa load time VPN dengan protocol SSTP untuk implementasi bridging web server SISTER yang berada dari jaringan private perguruan tinggi untuk dapat terhubung ke jaringan public atau internet.

Artikel ini bertujuan untuk menganalisa performa load time SISTER yang menggunakan koneksi VPN dengan protocol SSTP yang diterapkan untuk menghubungkan server SISTER yang ada pada jaringan private Perguruan Tinggi ke jaringan internet atau jaringan publik melalui beberapa skema pengujian dengan studi kasus Akademi Pariwisata Nusantara Jaya.

\section{Metode Penelitian}

Dalam melakukan penelitian ini menggunakan pendekatan eksperimen yang di mulai dari analisis implementasi yang sudah diterapkan, perancangan model pengujian, serta pengujian yang dijalankan berdasarkan tahap perancangan seperti gambar 1 di bawah ini. 


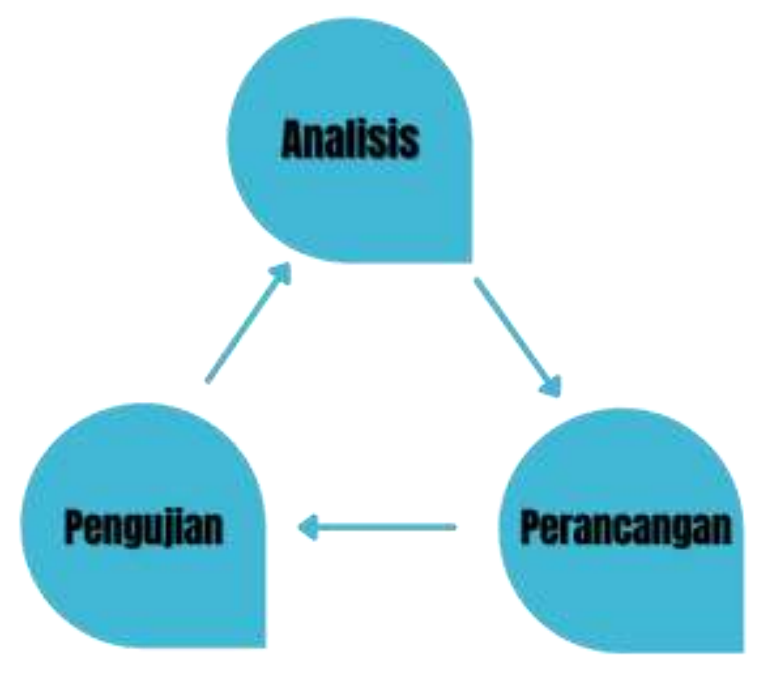

Gambar 1

Metode yang digunakan

\section{Analisa}

Analisis yang dilakukan adalah untuk mengetahui proses implementasi yang telah berjalan pada SISTER Akademi Pariwisata Nusantara Jaya dan layanan KampusGoPublic.



\section{Gambar 2}

Desain Implementasi SISTER - Kampus Go Public (KampusGoPublic, 2021)

Pada gambar 2 dapat dilihat implementasi NAT atau Network Address Translation. NAT merupakan sebuah model dimana memungkinkan jaringan internal terhubung dengan jaringan luar (Bansal \& Goel, 2017). NAT bekerja untuk sebagai penghubung antara jaringan privat dan jaringan publik yang dihubungkan dengan router. IP unik Pada jaringan publik nantinya akan mereprentasikan jaringan privat di belakangnya (Cisco, 2020). Ada 3 jenis NAT menurut (CompTia, 2021) yaitu Static NAT, Dynamic NAT dan PAT. Pada kasus ini implementasi SISTER Akpar NJ menggunakan NAT static dan PAT di mana IP Address serta Port akan ditranslasi ke jaringan dengan IP Address serta Port yang ditentukan. 


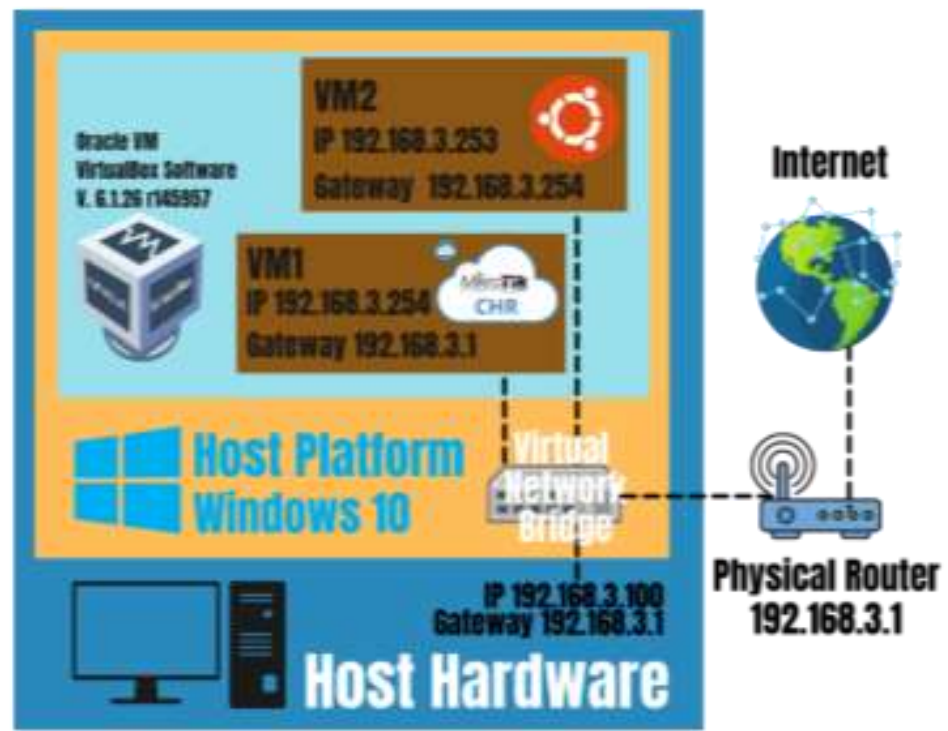

Gambar 3

Implementasi Virtual \& Physical Resource

Berdasarkan gambar 2 yang dianalisa lebih lanjut dapat dilihat implementasi server fisik dan virtual di Akademi Pariwisata Nusantara Jaya seperti pada gambar 3. Pada lapisan dasar terdapat host hadware atau server fisik dengan prosesor i7 seri 3000 \& memory 12GB. Pada lapisan ke 2 host menjalankan sistem operasi windows 10 profesional 64 bit. Dalam menjalankan virtualisasi pada lapisan ke 3 Akademi Nusantara Jaya Menggunakan Sofware Virtualisasi VirtualBox yang dapat di unduh pada link https://www.virtualbox.org/. Dibutuhkan dua buah virtual machine yang berjalan dalam Virtual Box yaitu Mikrotik CHR dan SISTER seperti pada tabel 1.

Tabel 1

Spesifikasi Virtual Machine AKPAR NJ

\begin{tabular}{ccccc}
\hline No. & Nama VM & Spesifikasi & $\begin{array}{c}\text { IP Address } \\
\text { Lokal }\end{array}$ & Fungsi \\
\hline 1 & SISTER & $\begin{array}{l}\text { 2 Core CPU, 2GB RAM, } \\
\text { Network Bridge Ethernet }\end{array}$ & 192.168.3.253 & $\begin{array}{c}\text { Web Server } \\
\text { Aplikasi SISTER }\end{array}$ \\
\hline 2 & $\begin{array}{c}\text { Mikrotik } \\
\text { CHR }\end{array}$ & $\begin{array}{c}\text { 1 CPU, 1GB RAM, Core } \\
\text { Network Bridge Ethernet }\end{array}$ & 192.168 .3 .254 & Virtual Router \\
\hline
\end{tabular}

Untuk Mikrotik CHR memiliki IP Static 192.168.3.254 dengan konfigurasi network brigde sehingga dapat langsung terkoneksi ke gateway router fisik (192.168.3.1), sedangkan SISTER memilki sistem operasi ubuntu 16.04 yang dikonfigurasi dengan IP static 192.168.3.253 yang diarahkan ke gateway Mikrotik CHR (192.168.3.254) agar nantinya fungsi NAT \& PAT dapat berjalan dengan baik untuk menghubungkan server SISTER ke jaringan internet. Implementasi dari gambar 3 dapat dilihat seperti gambar 4. 


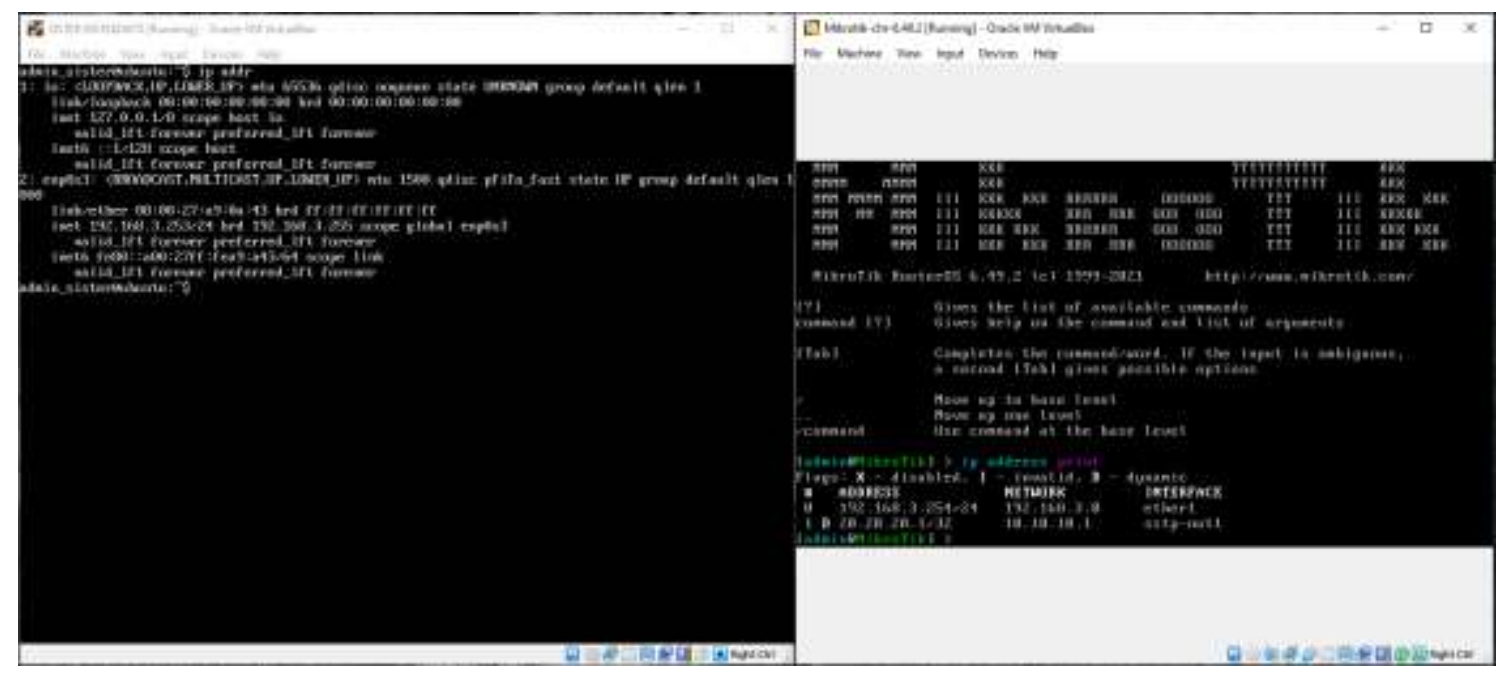

Gambar 4

VM SISTER dan Mikrotik CHR

Analisa terakhir adalah kondisi jaringan Akademi Pariwisata Nusantara Jaya yang dapat dilihat pada tabel 2. Terdapat 14 hop yang dilalui jaringan Akademi Pariwisata Nusantara Jaya menuju koneksi SSTP server KampusGoPublic. Kapasitas bandwidth Pariwisata sebesar 20Mbps dengan model shared tanpa IP Publik.

Tabel 2

Informasi Jaringan Lokal Server SISTER ke Server KampusGoPublic

\begin{tabular}{cccc}
\hline Koneksi & Total Hop & Provider & Speed \\
\hline Virtual Router CHR to & 14 & Indihome & 20Mbps \\
KampusGoPublic Server & 14 & & \\
\hline
\end{tabular}

\section{Perancangan}

Pada tahap ini perancangan pengujian adalah untuk mencari waktu yang dibutuhkan end-device atau host menampilkan halaman web aplikasi SISTER secara sempurna atau biasa disebut dengan (page load time). Pengujian yang dilakukan menggunakan peramban Google Chrome dengan versi 96.0.4664.110 64-bit. Pengujian page load time pada host menggunakan tiga provider internet yang berbeda seperti pada gambar 5 . 




Gambar 5

Skema Pengujian

Berdasarkan gambar 5, sampel yang diujikan adalah tiga halaman web pada aplikasi SISTER untuk mengukur waktu yang dibutuhkan setiap host pada gambar 5 dalam melakukan page load. Sampel yang halaman web SISTER yang diuji adalah halaman login dengan ukuran 1,2 MB, halaman dashboard dengan ukuran 2,4 MB serta halaman profil dengan ukuran 2,4 MB seperti pada tabel 3.

Tabel 3

Referensi Pengujian Page Load Time SISTER

\begin{tabular}{cccr}
\hline No. & $\begin{array}{c}\text { Nama } \\
\text { Halaman }\end{array}$ & $\begin{array}{c}\text { Page } \\
\text { Size } \\
\text { (MB) }\end{array}$ & Link \\
\hline 1 & Login & 1.2 & http://sister.kampusgopublic.web.id:10123/public/auth/login \\
\hline 2 & Dashboard & 2.4 & http://sister.kampusgopublic.web.id:10123/ \\
\hline 3 & Profil & 2.4 & http://sister.kampusgopublic.web.id:10123/profil/data_pribadi \\
\hline
\end{tabular}

Pengujian tiga sampel halaman web SISTER dari tabel 3 dilakukan sebanyak sepuluh kali dengan dua skema pengujian yang digunakan yaitu menerapkan konfigurasi "Cache Enable" serta "Cache Disable" pada peramban seperti pada tabel 4.

\section{Tabel 4}

Pengujian Load Time Halaman Login, Dashboard dan Profil

\begin{tabular}{lcccccc}
\hline & \multicolumn{9}{c}{ Load Time $(\mathbf{s})$} \\
\cline { 2 - 7 } No. Pengujian & \multicolumn{3}{c}{ Cache Enable } & \multicolumn{3}{c}{ Cache Disable } \\
\cline { 2 - 7 } & Host 1 & Host 2 & Host 3 & Host 1 & Host 2 & Host 3 \\
\hline Pengujian 1 & $\mathrm{xx}$ & $\mathrm{xx}$ & $\mathrm{xx}$ & $\mathrm{xx}$ & $\mathrm{xx}$ & $\mathrm{xx}$ \\
\hline Pengujian 2 & $\mathrm{xx}$ & $\mathrm{xx}$ & $\mathrm{xx}$ & $\mathrm{xx}$ & $\mathrm{xx}$ & $\mathrm{xx}$ \\
\hline$\ldots \ldots \ldots \ldots$. & $\ldots \ldots \ldots \ldots$ & $\ldots \ldots \ldots \ldots$ & $\ldots \ldots \ldots \ldots$ & $\ldots \ldots \ldots \ldots$ & $\ldots \ldots \ldots \ldots$ & $\ldots \ldots \ldots \ldots$ \\
\hline Pengujian 10 & $\mathrm{xx}$ & $\mathrm{xx}$ & $\mathrm{xx}$ & $\mathrm{xx}$ & $\mathrm{xx}$ & $\mathrm{xx}$ \\
\hline
\end{tabular}




\begin{tabular}{lccccccc}
\hline & \multicolumn{6}{c}{ Load Time (s) } \\
\cline { 2 - 7 } No. Pengujian & \multicolumn{3}{c}{ Cache Enable } & \multicolumn{4}{c}{ Cache Disable } \\
\cline { 2 - 7 } & Host 1 & Host 2 & Host 3 & Host 1 & Host 2 & Host 3 \\
\hline Rata-Rata & $\mathrm{xx}$ & $\mathrm{xx}$ & $\mathrm{xx}$ & $\mathrm{xx}$ & $\mathrm{xx}$ & $\mathrm{xx}$ \\
\hline
\end{tabular}

Langkah terakhir adalah menghitung waktu rata-rata yang dibutuhkan setiap host dengan tiga provider yang berbeda untuk menampilkan tiga sampel halaman web sister dengan konfigurasi "Cache Enable" serta "Cache Disable" pada web browser seperti pada tabel 5.

Tabel 5

Waktu Rata-Rata Pengujian Page Load Time Web SISTER Load Time (s)

\section{Cache Enable \\ Cache Disable}

\begin{tabular}{ccccccc}
\hline Page & Host 1 & Host 2 & Host 3 & Host 1 & Host 2 & Host 3 \\
\hline Halaman Login & $\mathrm{xx}$ & $\mathrm{xx}$ & $\mathrm{xx}$ & $\mathrm{xx}$ & $\mathrm{xx}$ & $\mathrm{xx}$ \\
\hline Halaman Dashboard & $\mathrm{xx}$ & $\mathrm{xx}$ & $\mathrm{xx}$ & $\mathrm{xx}$ & $\mathrm{xx}$ & $\mathrm{xx}$ \\
\hline Halaman Profil & $\mathrm{xx}$ & $\mathrm{xx}$ & $\mathrm{xx}$ & $\mathrm{xx}$ & $\mathrm{xx}$ & $\mathrm{xx}$ \\
\hline Rata-rata & $\mathrm{xx}$ & $\mathrm{xx}$ & $\mathrm{xx}$ & $\mathrm{xx}$ & $\mathrm{xx}$ & $\mathrm{xx}$ \\
\hline
\end{tabular}

\section{Hasil dan Pembahasan}

Berdasarkan referensi gambar 5, tabel 3 dan 4 berikut adalah hasil pengujian page load time halaman login, dashboard serta profil web SISTER dengan konfigurasi "Cache Enable" dan "Cache Disable" yang disajikan dalam matrik tabel 6, 7 dan 8.

Tabel 6

Pengujian Page Load Time Halaman Login

\begin{tabular}{|c|c|c|c|c|c|c|}
\hline \multirow{3}{*}{ No. Pengujian } & \multicolumn{6}{|c|}{ Load Time (s) } \\
\hline & \multicolumn{3}{|c|}{ Cache Enable } & \multicolumn{3}{|c|}{ Cache Disable } \\
\hline & Host 1 & Host 2 & Host 3 & Host 1 & Host 2 & Host 3 \\
\hline Pengujian 1 & 2,29 & 2,41 & 1,81 & 6,87 & 15,26 & 2,74 \\
\hline Pengujian 2 & 1,95 & 2,48 & 1,65 & 7,2 & 9,9 & 2,44 \\
\hline Pengujian 3 & 2,04 & 2,35 & 1,76 & 9,13 & 4,03 & 2,34 \\
\hline Pengujian 4 & 2,05 & 2,19 & 1,66 & 4,57 & 3,81 & 2,5 \\
\hline Pengujian 5 & 2,08 & 2,42 & 1,65 & 5,35 & 6,27 & 2,05 \\
\hline Pengujian 6 & 2,05 & 2,17 & 1,9 & 6,49 & 4,79 & 2,62 \\
\hline Pengujian 7 & 1,98 & 2,13 & 2,02 & 6,16 & 4,62 & 2,03 \\
\hline Pengujian 8 & 2,1 & 2,29 & 1,96 & 5,09 & 2,93 & 2,33 \\
\hline Pengujian 9 & 2,06 & 2,24 & 1,91 & 9,08 & 4,23 & 2,5 \\
\hline Pengujian 10 & 2,28 & 2,34 & 1,97 & 6,4 & 2,8 & 2,61 \\
\hline Rata-rata & 2,09 & 2,30 & 1,83 & 6,63 & 5,86 & 2,42 \\
\hline
\end{tabular}

Pengujian yang didapatkan dari tabel 6 dapat dilihat bahwa waktu rata-rata yang dibutuhkan dalam menampilkan halaman login web SISTER yang tercepat adalah pada host 3 pada mode Cache Enable dengan waktu 1,83 detik dan Cache Disable dengan waktu 2,42 detik. 
Tabel 7

Pengujian Load Time Halaman Dashboard

\begin{tabular}{lcccccc}
\hline & \multicolumn{6}{c}{ Load Time $(\mathbf{s})$} \\
\cline { 2 - 7 } No. Pengujian & \multicolumn{3}{c}{ Cache Enable } & \multicolumn{3}{c}{ Cache Disable } \\
\cline { 2 - 7 } & Host 1 & Host 2 & Host 3 & Host 1 & Host 2 & Host 3 \\
\hline Pengujian 1 & 2,08 & 1,96 & 1,84 & 18,73 & 9,94 & 3,55 \\
\hline Pengujian 2 & 2,54 & 2,02 & 1,89 & 12,85 & 7,76 & 3,23 \\
\hline Pengujian 3 & 1,88 & 1,9 & 1,64 & 13,48 & 7,27 & 6,4 \\
\hline Pengujian 4 & 1,83 & 2,03 & 1,81 & 9,54 & 6,02 & 3,98 \\
\hline Pengujian 5 & 1,98 & 2,04 & 1,87 & 8,16 & 8,24 & 3,32 \\
\hline Pengujian 6 & 1,82 & 2,04 & 1,87 & 10,31 & 8,62 & 3,85 \\
\hline Pengujian 7 & 1,97 & 2,18 & 1,82 & 8,11 & 6,07 & 3,75 \\
\hline Pengujian 8 & 1,85 & 2,22 & 1,81 & 13,14 & 5,84 & 5,61 \\
\hline Pengujian 9 & 2,14 & 2,15 & 1,95 & 17,36 & 4,85 & 5,77 \\
\hline Pengujian 10 & 2 & 2,06 & 1,86 & 14,12 & 5,42 & 6 \\
\hline Rata-rata & $\mathbf{2 , 0 1}$ & $\mathbf{2 , 0 6}$ & $\mathbf{1 , 8 4}$ & $\mathbf{1 2 , 5 8}$ & $\mathbf{7 , 0 0}$ & $\mathbf{4 , 5 5}$ \\
\hline
\end{tabular}

Pengujian yang didapatkan dari tabel 7 dapat dilihat bahwa waktu rata-rata yang dibutuhkan dalam menampilkan halaman dashboard web SISTER yang tercepat adalah pada host 3 pada mode Cache Enable dengan waktu 1,84 detik dan Cache Disable dengan waktu 4,55 detik.

Tabel 8

Pengujian Page Load Time Halaman Profil

\begin{tabular}{|c|c|c|c|c|c|c|}
\hline \multirow{3}{*}{ No. Pengujian } & \multicolumn{6}{|c|}{ Load Time (s) } \\
\hline & \multicolumn{3}{|c|}{ Cache Enable } & \multicolumn{3}{|c|}{ Cache Disable } \\
\hline & Host 1 & Host 2 & Host 3 & Host 1 & Host 2 & Host 3 \\
\hline Pengujian 1 & 1,75 & 1,6 & 1,82 & 15,33 & 6,47 & 3,75 \\
\hline Pengujian 2 & 1,49 & 1,7 & 1,55 & 14,09 & 7,9 & 3,22 \\
\hline Pengujian 3 & 1,65 & 1,7 & 1,53 & 13,72 & 8,05 & 3,8 \\
\hline Pengujian 4 & 1,68 & 1,63 & 1,55 & 9,85 & 4,91 & 4,14 \\
\hline Pengujian 5 & 1,61 & 1,9 & 1,55 & 9,18 & 7,4 & 4,09 \\
\hline Pengujian 6 & 1,66 & 1,59 & 1,56 & 10,12 & 7,09 & 3,68 \\
\hline Pengujian 7 & 1,62 & 1,5 & 1,61 & 10,05 & 8,26 & 3,74 \\
\hline Pengujian 8 & 1,62 & 1,54 & 1,47 & 13,31 & 7,77 & 5,06 \\
\hline Pengujian 9 & 1,54 & 1,6 & 1,59 & 16,78 & 5,22 & 5,55 \\
\hline Pengujian 10 & 1,64 & 1,82 & 1,64 & 15,53 & 4,93 & 6,71 \\
\hline Rata-rata & 1,63 & 1,66 & 1,59 & 12,80 & 6,80 & 4,37 \\
\hline
\end{tabular}

Pengujian yang didapatkan dari tabel 8 dapat dilihat bahwa waktu rata-rata yang dibutuhkan dalam menampilkan halaman profil web SISTER yang tercepat adalah pada host 3 pada mode Cache Enable dengan waktu 1,59 detik dan Cache Disable dengan waktu 4,37 detik.

Berdasarkan tabel 6, 7 dan 8 dapat diekstraksi Kembali menjadi matriks yang disajikan pada tabel tabel 9 untuk mendapatkan waktu page load rata-rata seluruh halaman. Dengan mode Cache Enable, host 1 membutuhkan waktu page load rata-rata 
sebesar 1,91 detik, host 2 membutuhkan waktu page load rata-rata sebesar 2,91 detik, host 3 membutuhkan waktu page load rata-rata sebesar 1,75 detik sehingga pada mode Cache Enable menjadi host 3 memiliki waktu tercepat untuk melakukan page load.

Tabel 9

Page Load Time Rata-Rata

\begin{tabular}{ccccccc}
\hline & \multicolumn{6}{c}{ Load Time (s) } \\
\hline Page & Host 1 & Host 2 & Host 3 & Host 1 & Host 2 & Host 3 \\
\hline Halaman Login & 2,09 & 2,3 & 1,83 & 6,63 & 5,86 & 2,42 \\
\hline Halaman Dashboard & 2,01 & 2,06 & 1,84 & 12,58 & 7 & 4,55 \\
\hline Halaman Profil & 1,63 & 1,66 & 1,59 & 12,58 & 6,8 & 4,37 \\
\hline Rata-rata & 1,91 & 2,01 & 1,75 & 10,60 & 6,55 & 3,78 \\
\hline
\end{tabular}

Pada mode Cache Disable tabel 9, host 1 membutuhkan waktu page load rata-rata sebesar 10,60 detik, host 2 membutuhkan waktu page load rata-rata sebesar 6,55 detik, host 3 membutuhkan waktu page load rata-rata sebesar 3,78 detik sehingga pada mode Cache Disable menjadi host 3 yang memiliki waktu tercepat untuk melakukan page load.

Berdasarkan tabel 9 yang divisualiasasikan dalam gambar 6 dapat dilihat bahwa mode Cache Enable dan Cache Disable dapat mempengaruhi waktu yang dibutuhkan tiap host dalam melakukan page load. Pada mode Cache Enable memungkinkan host untuk menyimpan asset pada request page pertama ke web server untuk meminimalisir perulangan proses unduh asset pada request page ke 2, 3, dst ke web server sehingga pada mode ini host 1, host 2 dan host 3 mendapatkan waktu load page yang optimal dengan perolehan waktu di bawah 3 detik. Sedangkan mode Cache Disable memungkinkan perulangan proses unduh asset pada setiap proses request page host ke web server sehingga pada mode ini host 1 , host 2 dan host 3 mengalami penambahkan waktu load page 2 kali lipat dibadingkan mode Cache Enable

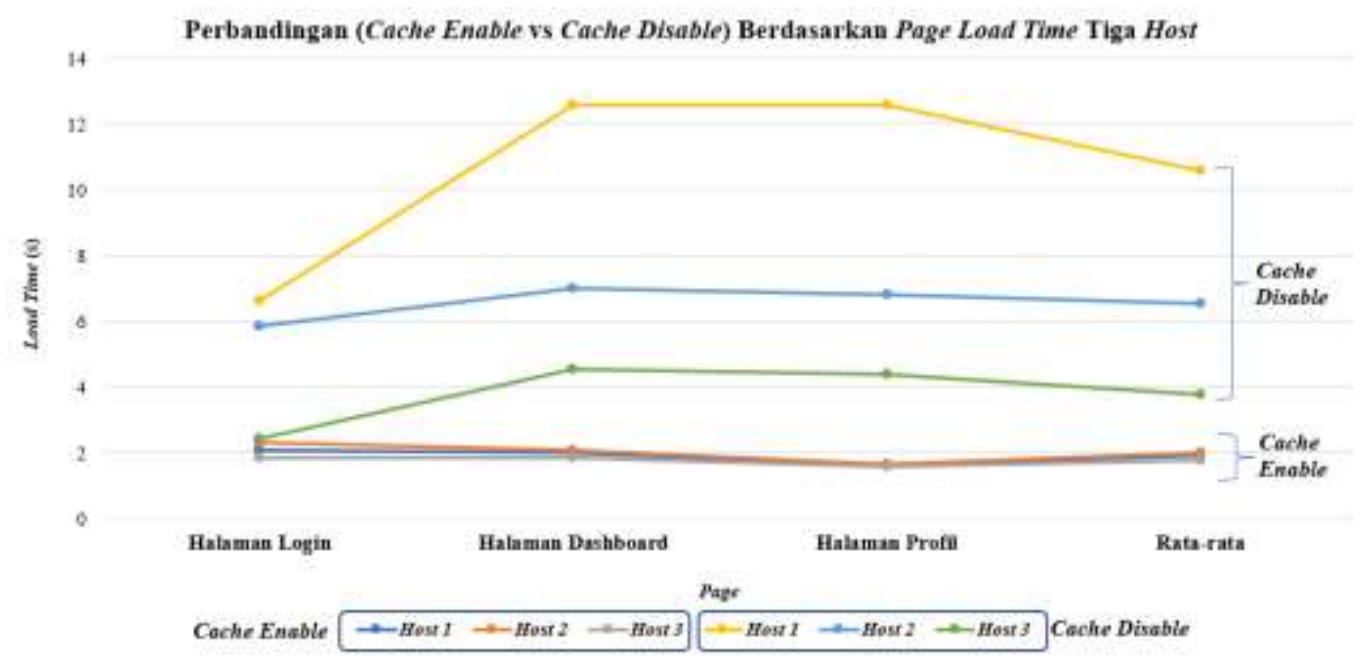

Gambar 6

Perbandingan (Cache Enable vs Cache Disable) Berdasarkan Page Load Time Host Yang menggunakan Tiga Provider Berbeda 
Berdasarkan gambar 6 dapat dilihat bahwa hasil pengujian yang dilakukan sesuai dengan hasil pengujian (Carol et al., 2017) dimana SSTP unggul dalam hal file transfer atau file download. Hasil pengujian yang dapat dilihat pada gambar 6, proses yang dibutuhkan untuk melakukan transfer data halaman web dengan ukuran halaman sebesar 2,4 MB dari web server SISTER - VPN server - host membutuhkan waktu yang relatif singkat dengan waktu kurang lebih 2 detik.

\section{Kesimpulan}

Waktu yang dibutuhkan untuk menampilkan halaman web SISTER bervariasi tergantung dari media yang digunakan. Media wireless yang digunakan pada host 1 dan host 2 relatif lambat untuk menampilkan halaman web dibandingkan dengan media wired yang digunakan host 3 baik pada skema pengujian cache enable dan cache disable pada konfigurasi peramban Google Chrome. Skema pengujian konfigurasi cache enable meningkatkan kecepatan waktu untuk menampilkan halaman web SISTER lebih dari 2 kali lipat dibandingkan dengan konfigurasi cache disable.

Dapat simpulkan bahwa layanan KampusGoPublic yang menggunakan metode VPN SSTP berjalan dengan baik untuk implementasi akses public SISTER sehingga server SISTER pada jaringan lokal perguruan tinggi dapat diakses dari jaringan internet menggunakan konsep VPN SSTP, NAT dan PAT. Untuk performa akses terbaik gunakan media wired dan dengan hop terkecil menuju gateway server KampusGoPublic. 


\section{BIBLIOGRAFI}

Aleshin, I.; Vasiliev, A.; Kholodkov, K.; Perederin, F. (2015). Virtual private network technologies in real-time geophysical data collection systems. Seismic Instruments, 51(Allerton Press, Inc.), 44-47. https://link.springer.com/article/10.3103/S074792391501003X. Google Scholar

Azhar, R. (2017). Analisa Qos Pada Jaringan Site To Site Vpn. Analisa Qos Pada Jaringan Site To Site Vpn Menggunakan Protocol Sstp, 52-60. Google Scholar

Bansal, A., \& Goel, P. (2017). Simulation and Analysis of Network Address Translation (NAT) \& Port Address Translation (PAT) Techniques. International Journal of Engineering Research and Applications, 07(07), 50-56. Google Scholar

Carol, D., Rijke, G., Himamunanto, R., Si, S., Kom, M., Si, S., Kom, M., Sains, F., \& Immanuel, U. K. (2017). Analisis Perbandingan Performa SSTP Dan PPTP Pada VPN. Jurnal Sains Dan .., journal.ukrim.ac.id/index.php/JFE/article/download/126/101. Google Scholar

Cisco. (2020). Network Address Translation (NAT) FAQ. https://www.cisco.com/c/en/us/support/docs/ip/network-address-translationnat/26704-nat-faq-00.html.

CompTia. (2021). What Is NAT? https://www.comptia.org/content/guides/what-isnetwork-address-translation.

Farly, K. A., Najoan, X. B. N., \& Lumenta, A. S. M. (2017). Perancangan Dan Implementasi Vpn Server Dengan Menggunakan Protokol Sstp (Secure Socket Tunneling Protocol) Studi Kasus Kampus Universitas Sam Ratulangi. Jurnal Teknik Informatika Unsrat, (11(1), 143279. Google Scholar

Hariyadi, I. P. (2017). Sentralisasi Manajemen Hotspot Menggunakan Transparent Bridge Tunnel EoIP over SSTP. Jurnal Matrik, 16(2), 86. Google Scholar

Hariyadi, I. P., \& Azhar, R. (2017). Pengamanan Layanan Private Cloud Storage Menggunakan HTTPS, IPTables dan SSTP. Seminar Nasional TIK Dan Ilmu Sosial. Google Scholar

KampusGoPublic. (2021). Official KampusGoPublic Website. https://kampusgopublic.web.id/v1/about/

Rasuanda, M., \& Haeruddin. (2020). Perbandingan Performa VPN Menggunakan PPTP Dan SSTP Over SSL Dengan Metode Quality of Service. Journal of Information System and Technology, 01(02), 110-123. Google Scholar

Ruslianto, Ikhwan;Ristian, U. (2019). Perancangan dan Implementasi Virtual Private Network (VPN) menggunakan Protokol SSTP (Secure Socket Tunneling Protocol) Mikrotik di Fakultas MIPA Universitas Tanjungpura. Computer Engineering, 
Firman Pratama

Science and System Journal, 4(1), 74. Google Scholar

Santoso, B., Sani, A., Husain, T., \& Hendri, N. (2021). Vpn Site To Site Implementation Using Protocol L2Tp and Ipsec. Teknokom, 4(1), 30-36. Google Scholar

Sugiyatno, \& Atika, P. D. (2018). Virtual Private Network (VPN) Secure Socket Tunneling Protocol (SSTP) Menggunakan Raspberry Pi. Information System For Educators And Professionals, 2(2), 155-166. Google Scholar

Zamalia, W. O., Aksara, L. M. F., \& Yamin, M. (2018). Analisis Perbandingan Performa Qos, Pptp, L2Tp, Sstp Dan Ipsec Pada Jaringan Vpn Menggunakan Mikrotik. SemanTIK, 4(2), 29-36. Google Scholar

\section{Copyright holder:}

Firman Pratama (2022)

\section{First publication right:}

Syntax Idea

This article is licensed under:

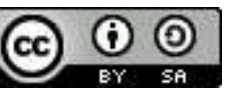

